\title{
Pengaruh Pemberian Informasi Obat Antihipertensi terhadap Tingkat Pengetahuan dan Kepatuhan Pasien Peserta PROLANIS di Puskesmas Gedangan Kabupaten Malang
}

\author{
Ayuk Lawuningtyas Hariadini ${ }^{*}$, Septian Secsiandre Ade Pamungkas ${ }^{1}$, Bambang Sidharta ${ }^{1}$ \\ ${ }^{1}$ Jurusan Farmasi, Fakultas Kedokteran, Universitas Brawijaya, Malang, Indonesia
}

INFO ARTIKEL

Sejarah artikel:

Penerimaan

naskah: 17 Juli

2020

Penerimaan naskah

revisi: 9 Desember

2020

Disetujui untuk

dipublikasikan: 9

Desember 2020

\begin{tabular}{l}
\hline Kata kunci : \\
Pemberian \\
informasi obat, \\
pengetahuan, \\
kepatuhan, \\
hipertensi, Prolanis
\end{tabular}

\author{
A B S T R A K
}

Penyakit kardiovaskuler khususnya hipertensi memerlukan penanganan yang tepat karena dapat menimbulkan komplikasi seperti stroke, gagal jantung dan penyakit ginjal. Pemberian informasi obat oleh apoteker merupakan salah satu faktor yang dapat meningkatkan pengetahuan pasien dalam memahami penyakit yang dideritanya sehingga dapat berpengaruh terhadap tingkat kepatuhan minum obat pasien. Tujuan dari penelitian yaitu mengetahui pengaruh pemberian informasi obat terhadap tingkat pengetahuan dan kepatuhan pasien hipertensi peserta prolanis di Puskesmas Gedangan Kabupaten Malang. Metode penelitian ini adalah quasi eksperimental dengan desain one grup pre-test post-test. Pemilihan responden dilakukan menggunakan metode purposive sampling. Populasi dalam penelitian ini adalah pasien hipertensi yang terdaftar dalam program pengelolaan penyakit kronis di Puskesmas Gedangan, dan didapatkan sejumlah 68 responden yang memenuhi kriteria inklusi. Instrumen yang digunakan pada penelitian ini yaitu kuesioner pengetahuan Hypertension Knowledge-Level Scale (HK-LS) yang terdiri dari 22 pertanyaan, serta kuesioner Kepatuhan Morisky Medication Adherence Scale (MMAS-8) yang sebelumnya telah diuji validitas dan reliabilitasnya. Penelitian ini sudah memenuhi laik etik dari Fakultas Kedokteran Universitas Brawijaya dengan nomor 80/EC/KEPK-S1-FARM/04/2020. Data yang didapatkan dianalisis statistik menggunakan uji t berpasangan untuk mengetahui hubungan antara kedua variabel. Nilai uji t berpasangan menunjukkan tingkat pengetahuan meningkat secara signifikan $(p=0,000)$ kepatuhan meningkat dengan signifikan $(p=0,000)$ setelah pemberian informasi obat. Kesimpulan dari penelitian ini adalah terdapat perbedaan yang signifikan antara tingkat pengetahuan dan kepatuhan sebelum dan setelah dilakukan pemberian informasi obat di Puskesmas Gedangan Kabupaten Malang.

\section{The Influence of Providing Antihypertensive Drug Information on the Level of Knowledge and Adherence of Prolanis Patients at Gedangan Health Center in Malang Districts}

\section{Keywords:}

Drug Information,

knowledge,

adherence,

hypertension,

Prolanis

\section{A B S T R A C T}

Cardiovascular disease especially hypertension requires proper treatment because it can cause complication such as stroke, heart failure and kidney disease. Provision of drug informasion is one of the factors that can increase the patient's knowledge in understanding the illness so that it can affect the patient's level of medication adherence. The purpose of the study was to determine the influence of providing drug information on the level of knowledge and adherence of hypertensive patients at Gedangan Health Center in Malang Districs. This research method is a quasi-experimental with one group pre-test post-test design. Purposive sampling method was used to the selection of respondents. There were 68 respondents who met the inclusion criteria was found. Hypertension patients are patients that registered in the chronic disease management program at Gedangan Health Center. The instrument used in this study was a knowledge questionnaire consisting 22 questions, as well as the Morisky Medication Adherence Scale (MMAS-8) adherencequestionnaire, whichhad previously been tested for validity and reliability. The results of the study were seen from the knowledge and compliance questionnaire score pre-test and post-test. Faculty of Medicine Universitas Brawijaya has ethically approved the research by the number 80/EC/KEPK-S1-FARM/04/2020. The data obtained were statistically analyzed using paired t-test to determine the relationship between the two variables. Paired t-test scores showed that the level of knowledge increased significantly $(p=0.000)$ and adherence increased significantly $(\mathrm{p}=0.000)$ after drug information administration. The conclusion of this study was that there was a significant difference between the level of knowledge and adherence before and after the provision of drug information at Gedangan Health Center of Malang Regency.

\footnotetext{
* Corresponding author: Ayuk Lawuningtyas H, Jurusan Farmasi, Fakultas Kedokteran, Universitas Brawijaya, Jalan Veteran Malang.

E-mail:ayukhariadini@ub.ac.id.
} 


\section{Pendahuluan}

Hipertensi merupakan penyakit kronik yang ditandai dengan naiknya tekanan darah. Berdasarkan Joint Nasional Committe (JNC) VIII dikatakan hipertensi jika tekanan darah $(>140 / 90 \mathrm{mmHg})^{1}$. Komplikasi dari tekanan darah yang meningkat pada jangka waktu yang lama dapat menyebabkan kerusakan pada ginjal, penyakit jantung dan otak.

Menurut WHO, pada kelompok umur diatas 45 tahun, penyakit kardiovaskular merupakan penyakit utama yang dapat menyebabkan kematian. Sekitar 12 juta penduduk dunia yang meninggal setiap tahunnya ${ }^{2}$. Berdasarkan Riskesdas 2018, prevalensi hipertensi pada usia $\geq 18$ tahun di indonesia sebesar $34,1 \%$. Provinsi Jawa Timur berada di urutan ke- 6 sebagai daerah dengan prevalensi hipertensi terbanyak pada usia $\geq 18$ tahun di Indonesia ${ }^{3}$. Berdasarkan data Dinas Kesehatan Jawa Timur 2017, didapatkan kasus hipertensi sebesar 20, 43\% atau sekitar 1. 828. 669 penduduk, dengan proporsi laki-laki sebesar 20, 83\% (825. 412 penduduk) dan perempuan sebesar 20, $11 \%$ (1. 003. 257 penduduk) ${ }^{4}$. Data penderita hipertensi Kabupaten Malang tahun 2017 menunjukkan bahwa kasus hipertensi sebesar $9 \%$. Berdasarkan studi pendahuluan yang telah dilakukan di Puskesmas Gedangan didapatkan laporan prevalensi hipertensi pada tahun 2018 sebesar 21, $73 \%$.

Berdasarkan Peraturan Menteri Kesehatan Republik Indonesia nomor 74 tahun 2016 pelayanan kefarmasian di Puskesmas telah mengalami perubahan yang semula hanya berfokus kepada pengelolaan obat (drug oriented) berkembang menjadi pelayanan komprehensif meliputi pelayanan obat dan pelayanan farmasi klinik yang bertujuan untuk meningkatkan kualitas hidup Pasien. Apoteker dituntut untuk meningkatkan pengetahuan, keterampilan, dan perilaku agar dapat melaksanakan interaksi langsung dengan pasien. Bentuk interaksi tersebut antara lain adalah pemberian informasi obat dan konseling kepada pasien. Hal tersebut akan memberikan pemahaman yang benar mengenai Obat kepada pasien/keluarga pasien antara lain tujuan pengobatan, jadwal pengobatan, cara dan lama penggunaan obat, efek samping, tanda-tanda toksisitas, cara penyimpanan, dan penggunaan obat ${ }^{5}$.

Prolanis (program pengelolaan penyakit kronis) adalah salah satu program pemerintah untuk penyakit kronis, Pelayanan Prolanis di fasilitas kesehatan primer saat ini lebih fokus pada pemberian konsultasi medis, informasi dan edukasi terkait penyakit kronis kepada penderita dan keluarga yang tentunya dapat mempengaruhi sikap kepatuhan pasien dalam mengkonsumsi obat yang penggunaannya memerlukan jangka waktu yang panjang ${ }^{6}$.
Dengan adanya program Prolanis ini diharapkan kualitas hidup penderita dapat meningkat.

Pengetahuan pasien terhadap penyakit yang dideritanya merupakan salah satu aspek yang berpengaruh terhadap tingkat kepatuhan. Menurut hasil penelitian terdahulu mengenai pasien Prolanis di Puskesmas Kota Batu, peningkatan pengetahuan tentang penyakit dan obat hipertensi dapat meningkatkan kepatuhan $(\mathrm{p}=0,010)^{7}$. Kepatuhan merupakan suatu tindakan atau perilaku pasien yang menggambarkan sejauh mana pasien taat terhadap ketentuan yang diberikan oleh professional kesehatan. Kepatuhan minum obat sangat penting terutama bagi pasien penyakit kronis. Salah satu indikator dari kepatuhan pasien minum obat antihipertensi adalah terkontrolnya tekanan darah.

Ketidakpatuhan pasien dalam penggunaan obat merupakan kegagalan terapi yang paling sering terjadi. Berdasarkan latar belakang permasalahan di atas, penulis ingin meneliti mengenai pengaruh pemberian informasi obat antihipertensi terhadap tingkat pengetahuan dan kepatuhan penggunaan obat hipertensi pada pasien hipertensi peserta Prolanis di Puskesmas Gedangan Kabupaten Malang.

\section{Metode}

Penelitian ini berjeni squasi eksperimental dengan desain pretest - posttest control group yang menjelaskan pengaruh pemberian informasi obat antihipertensi dengan tingkat kepatuhan penderita hipertensi di Puskesmas Gedangan Kabupaten Malang pada bulan Januari sd Februari 2020.

Berdasarkan studi pendahuluan, didapatkan jumlah populasi pasien hipertensi peserta Prolanis sejumlah 52 pasien. Jumlah sampel minimum dihitung menggunakan rumus slovin sebagai berikut:

$$
\begin{gathered}
n=\frac{N}{1+\left(N x e^{2}\right)} \\
=\frac{52}{1+\left(52 x 0,05^{2}\right)}=46, \quad 2 \approx 46
\end{gathered}
$$

Keterangan:

$$
\begin{array}{ll}
\mathrm{n} & =\text { Jumlah sampel minimal } \\
\mathrm{N} & =\text { Populasi } \\
\mathrm{e} & =\text { Error margin }
\end{array}
$$

Diperoleh jumlah sampel minimum sebanyak 46 pasien dengan kriteria inklusi sebagai berikut: (1) terdiagnosis hipertensi, (2) dapat berkomunikasi dengan 
baik secara tertulis atau lisan, dan (3) berkenan menjadi responden.

Instrumen penelitian yang digunakan berupa 22 butir pertanyaan kuesioner modifikasiHypertension Knowledge-Level Scale (HK-LS) untuk mengukur tingkat pengetahuan dan 8 butir kuesioner modifikasiMorisky Medication Adherence Scale (MMAS-8) untuk mengukur tingkat kepatuhan. Kedua kuesioner tersebut telah melalui uji validitas dan reliabilitas kepada 30 responden dengan kriteria inklusi yang sama dengan sampel.

Skor pengetahuan dan kepatuhan pre dan post perlakuan yang diperoleh, diuji normalitas untuk mengetahui distribusi datanya. Dilakukan uji $t$ berpasangan jika data berdistribusi normal dan jika data tidak berdistribusi normal dilakukan uji alternatif, yaitu uji wilcoxon.

\section{Hasil dan Diskusi}

Berdasarkan data yang didapatkan dari pasien hipertensi di Puskesmas Gedangan, diperoleh data karakteristik responden sebagai berikut:

Tabel 1. Karakteristik Responden

\begin{tabular}{|c|c|c|c|}
\hline & Variabel & Frekuensi (n) & $\begin{array}{c}\text { Persentase } \\
(\%)\end{array}$ \\
\hline \multirow{3}{*}{$\begin{array}{c}\text { Jenis } \\
\text { Kelamin }\end{array}$} & Laki - Laki & 23 & 34 \\
\hline & Perempuan & 45 & 66 \\
\hline & Total & 68 & 100 \\
\hline \multirow{2}{*}{$\begin{array}{c}\text { Pendidikan } \\
\text { Terakhir }\end{array}$} & $\begin{array}{c}\text { Tidak } \\
\text { Sekolah }\end{array}$ & 5 & 7,4 \\
\hline & $\begin{array}{c}\text { Tidak } \\
\text { tamat } \\
\text { SD }\end{array}$ & 13 & 19,1 \\
\hline \multirow{5}{*}{$\begin{array}{c}\text { Pendidikan } \\
\text { Terakhir }\end{array}$} & SD & 18 & 26,5 \\
\hline & SMP & 12 & 17,6 \\
\hline & SMA & 17 & 25 \\
\hline & Diploma & 3 & 4,4 \\
\hline & Total & 68 & 100 \\
\hline \multirow{2}{*}{ Usia } & $<50$ tahun & 12 & 17,6 \\
\hline & $>50$ tahun & 56 & 82,4 \\
\hline
\end{tabular}

\begin{tabular}{|c|c|c|c|}
\hline & Variabel & Frekuensi (n) & Persentase \\
\hline & Total & 468 & 100 \\
\hline \multirow{7}{*}{ Pekerjaan } & PNS & 7 & 10,3 \\
\hline & Pegawai Swasta & 14 & 20,6 \\
\hline & Ibu Rumah Tangga & 6 & 8,8 \\
\hline & Petani & 30 & 44,1 \\
\hline & Tidak Bekerja & 10 & 14,7 \\
\hline & Pensiunan & 1 & 1,5 \\
\hline & Total & 68 & 100 \\
\hline \multirow{3}{*}{$\begin{array}{c}\text { Lama } \\
\text { Menderita } \\
\text { Hipertensi }\end{array}$} & $\leq 5$ tahun & 44 & 64,7 \\
\hline & $>5$ tahun & 24 & 35,3 \\
\hline & Total & 68 & 100 \\
\hline
\end{tabular}

Pasien perempuan lebih banyak dari pada pasien laki-laki dengan persentase laki-laki 34\% dan perempuan $66 \%$. Pasien hipertensi lebih banyak berusia $>50$ tahun dengan persentase sebanyak $82,4 \%$ (56 responden) dibanding dengan pasien dengan usia $<50$ tahun sebesar 17, $6 \%$ (12 responden). Pria dengan umur $>45$ tahun lebih banyak menderita hipertensi dibandingkan wanita ${ }^{8}$. Tetapi dari umur 55 sampai dengan 74 tahun sedikit lebih banyak perempuan dibandingkan laki-laki yang menderita hipertensi ${ }^{9}$.

Pendidikan terakhir responden paling banyak adalah SD sebesar 26, 5\% (18 responden) dan yang paling sedikit adalah Diploma sebesar 4, $4 \%$ (3 responden). Tingkat pendidikan berpengaruh terhadap kualitas hidup seseorang, dimana semakin tinggi pendidikan maka penerimaan terhadap informasi akan semakin baik ${ }^{10}$.

Pekerjaan pasien yang terbanyak adalah sebagai petani44, 1\% (30responden), dan paling sedikit pasien dengan pekerjaan Pensiunan sebesar 1, 5\% (1 responden). Status pekerjaan juga dapat mempengaruhi terjadinya hipertensi dengan prevalensi sebesar 24, $72 \%$. Hipertensi sangat dipengaruhi oleh makanan yang dikonsumsi dan pekerjaan yang menguras aktivitas masyarakat sehingga mengurangi pola aktivitas yang baik untuk dilakukan ${ }^{3}$.

Sebagian besar responden telah menderita hipertensi selama $\leq 5$ tahun dengan persentase $64,7 \%$ (44 responden). Lama menderita hipertensi berkaitan langsung 
dengan faktor risiko terjadinya komplikasi. Semakin lama hipertensi maka semakin tinggi risiko terjadinya penyakit jantung koroner $^{8}$. Semakin lama seseorang menderita hipertensi maka tingkat kepatuhannya semakin rendah ${ }^{11}$.

Profil pengetahuan responden terhadap hipertensi dan terapinya dapat dilihat pada tabel 2 berikut:

Tabel 2. Profil Pengetahuan Responden

\begin{tabular}{|c|c|c|c|c|c|}
\hline \multirow{2}{*}{ No. } & \multirow{2}{*}{ Indikator } & \multicolumn{2}{|c|}{ Bulan Ke-0 } & \multicolumn{2}{|c|}{ Bulan Ke-1 } \\
\hline & & Benar & Salah & Benar & Salah \\
\hline 1 & Definisi & $84,7 \%$ & $15,3 \%$ & $96,7 \%$ & $3,3 \%$ \\
\hline 2 & $\begin{array}{l}\text { Terapi } \\
\text { Farmakologi } \\
\text { s }\end{array}$ & $60,9 \%$ & $39,1 \%$ & $65,2 \%$ & $\begin{array}{l}43 \\
8 \%\end{array}$ \\
\hline 3 & $\begin{array}{l}\text { Kepatuhan } \\
\text { Pengobatan }\end{array}$ & $27,2 \%$ & $72,8 \%$ & $47,8 \%$ & $\begin{array}{l}52 \\
2 \%\end{array}$ \\
\hline 4 & Gaya Hidup & $59,6 \%$ & $40,4 \%$ & $60 \%$ & $40 \%$ \\
\hline 5 & $\begin{array}{l}\text { Diet/Makana } \\
\mathrm{n}\end{array}$ & $48,9 \%$ & $51,1 \%$ & $46,7 \%$ & $\begin{array}{l}53 \\
3 \%\end{array}$ \\
\hline 6 & Komplikasi & $85,7 \%$ & $14,3 \%$ & $89,6 \%$ & $\begin{array}{l}10 \\
4 \%\end{array}$ \\
\hline
\end{tabular}

Peningkatan pengetahuan terhadap indikator terapi farmakologi tidak terlalu tinggi sebab masih banyak pasien yang meminum obat anti hipertensi saat muncul gejala saja. Hipertensi biasanya menimbulkan sedikit gejala saja pada stadium lanjut. Sekali diagnosis hipertensi ditegakkan, harus dipertimbangkan apakah perlu diobati dan jenis obat apa yang paling tepat. Pemilihan obat didasarkan pada tekanan darah, umur dan jenis kelamin, keberadaan dan beratnya kerusakan organ, adanya risiko penyakit kardiovaskular, dan adanya penyakit komorbid ${ }^{12}$.

Gaya hidup pasien merupakan salah satu faktor yang sulit dikontrol pada terapi hipertensi. Peningkatan pengetahuan sangat kecil, hanya $0,4 \%$ dan rata-rata hanya $60 \%$ pasien menjawab benar untuk pertanyaan: (1) apakah perubahan gaya hidup dapat menurunkan tekanan darah, (2) apakah makanan asin dapat memicu peningkatan tekanan darah, (3) apakah minuman beralkohol dan rokok dapat memicu peningkatan tekanan darah, serta (4) apakah metode memasak dengan dipanggang dan digoreng dapat memicu peningkatan tekanan darah.

Penatalaksanaan nutrisi pasien hipertensi bertujuan untuk membantu menurunkan tekanan darah dan mempertahankan tekanan darah menjadi normal. Pengaturan diet juga bertujuan untuk menurunkan faktor risiko lain, seperti berat badan yang berlebih, tingginya kadar lemak kolesterol, dan asam urat dalam darah ${ }^{13}$. Diet yang saat ini direkomendasikan oleh JNC untuk hipertensi adalah Dietary Approach to Stop Hypertension (DASH), yaitu diet yang kaya akan buah, sayur, dan produk makanan rendah lemak ${ }^{1}$.
Pasien Prolanis selanjutnya mendapatkan informasi obat dari apoteker penanggung jawab ruang farmasi yang meliputi definisi hipertensi, nama dan kekuatan obat, indikasi, aturan pakai, lama penggunaan, efek samping, perubahan gaya hidup, pengaturan pola makan, serta komplikasi hipertensi. Peningkatan pengetahuan dan kepatuhan pasien terlihat pada tabel 3 dan 4 sebagai berikut:

Tabel 3. Peningkatan Pengetahuan Responden

\begin{tabular}{lcccc}
\hline \multirow{2}{*}{$\begin{array}{l}\text { Tingkat } \\
\text { Pengetahuan }\end{array}$} & \multicolumn{2}{c}{ Bulan Ke-0 } & \multicolumn{2}{c}{ Bulan Ke-1 } \\
\cline { 2 - 5 } & $\mathbf{n}$ & $\%$ & $\mathbf{n}$ & $\%$ \\
\hline Baik & 25 & 54,3 & 29 & 63 \\
\hline Cukup & 20 & 43,5 & 12 & 26,1 \\
\hline Kurang & 1 & 2,2 & 5 & 10,9 \\
\hline Total & 46 & 100 & 46 & 100 \\
\hline
\end{tabular}

Tabel 4. Peningkatan Kepatuhan Pasien

\begin{tabular}{lcccc}
\hline \multirow{2}{*}{$\begin{array}{l}\text { Tingkat } \\
\text { Kepatuhan }\end{array}$} & \multicolumn{2}{c}{ Bulan Ke-0 } & \multicolumn{2}{c}{ Bulan Ke-1 } \\
\cline { 2 - 5 } & $\mathbf{n}$ & $\%$ & $\mathbf{n}$ & $\%$ \\
\hline Baik & 6 & 13 & 7 & 15,2 \\
\hline Cukup & 10 & 21,7 & 16 & 34,8 \\
\hline Kurang & 30 & 65,3 & 23 & 50 \\
\hline Total & 46 & 100 & 40 & 100 \\
\hline
\end{tabular}

Berdasarkan hasil uji validitas, semua kuesioner pengetahuan dan kepatuhan dinyatakan valid dengan nilai probabilitas korelasi [sig. (2-tailed)]< taraf signifikansi $(\alpha)$ sebesar 0, 05. Uji reliabilitas menunjukkan nilai Cronbach's Alpha 0, 856 untuk kuesioner pengetahuan dan 0, 816 untuk kuesioner kepatuhan. Nilai Cronbach's Alpha tersebut memenuhi kriteria yaitu antara $>0,7-0,9$ yang menunjukkan reliabilitas tinggi.

Uji normalitas pada penelitian ini menggunakan Uji Shapiro-Wilk karena jumlah sampelnya kurang dari 50 responden. Pada penelitian ini uji normalitas dilakukan pada kuesioner pengetahuan (pre-test dan post-test bulan ke-1) dan kuesioner kepatuhan (pre test dan post test bulan ke-1. Pada penelitian ini, didapatkan nilai signifikansi $>0$, 05 sehingga data dikatakan berdistribusi normal seperti terlihat pada tabel 5 berikut:

Tabel 5. Hasil Uji Normalitas

\begin{tabular}{llll}
\hline No. & Data & $\begin{array}{l}\text { Nilai } \\
\text { Signifikansi }\end{array}$ & Keterangan \\
\hline 1 & $\begin{array}{l}\text { Kuesioner } \\
\text { Pengetahuan pre } \\
\text { test }\end{array}$ & 0,184 & $\begin{array}{l}\text { Berdistribusi } \\
\text { normal }\end{array}$ \\
\hline 2 & Kuesioner & 0,466 & Berdistribusi \\
\hline
\end{tabular}




\begin{tabular}{llll}
\hline & $\begin{array}{l}\text { Kepatuhan pre } \\
\text { test }\end{array}$ & normal \\
\hline 3 & $\begin{array}{l}\text { Kuesioner } \\
\text { pengetahuan } \\
\text { post test }\end{array}$ & 0,687 & $\begin{array}{l}\text { Berdistribusi } \\
\text { normal }\end{array}$ \\
\hline 4 & $\begin{array}{l}\text { Kuesioner } \\
\text { kepatuhan post } \\
\text { test }\end{array}$ & 0,250 & $\begin{array}{l}\text { Berdistribusi } \\
\text { normal }\end{array}$ \\
\end{tabular}

Karena data berdistribusi normal, maka dipilih metode uji $\mathrm{t}$ berpasangan untuk analisis komparasi tingkat pengatahuan dan kepatuhan sebelum dan sesudah pemberian informasi obat oleh apoteker di ruang farmasi. Hasil uji t berpasangan dapat dilihat pada tabel 6 berikut ini:

Tabel 6. Hasil Uji t Berpasangan

\begin{tabular}{lll}
\hline Data & $\begin{array}{l}\text { Nilai } \\
\text { Signifikansi }\end{array}$ & Keterangan \\
\hline $\begin{array}{l}\text { Perbandingan } \\
\text { tingkat pengetahuan }\end{array}$ & 0,000 & Signifikan \\
sebelum dan & & \\
sesudah pemberian & & \\
informasi obat & & \\
\hline $\begin{array}{l}\text { Perbandingan Signifikan } \\
\text { tingkat kepatuhan } \\
\text { sebelum } 0,000\end{array}$ \\
sesudah pemberian \\
informasi obat
\end{tabular}

Berdasarkan penelitian yang dilakukan, diperoleh hasil semakin tinggi tingkat pengetahuan seseorang, maka semakin tinggi tingkat kepatuhan minum obat pada penderita tersebut. Ini berarti pengetahuan memiliki peran penting terhadap tingkat kepatuhan seseorang dalam menjalani proses pengobatan. Hal yang sama juga dikemukakan oleh Notoatmodjo, dimana pengetahuan merupakan salah satu faktor yang berhubungan dengan kepatuhan seseorang dalam menjalani pengobatan. Semakin baik pengetahuan seseorang, maka dapat meningkatkan kepatuhan seseorang dalam menjalani proses pengobatan ${ }^{14}$.

Hal ini juga sejalan dengan penelitian yang dilakukan di India Selatan, bertujuan untuk mengukur pengaruh konseling farmasi dalam meningkatkan pengetahuan dan kepatuhan pasien rawat jalan. Skor ratarata pengetahuan kelompok perlakuan dengan kelompok kontrol yaitu 13, $82 \pm 1,8064$ dan 11, 78 $\pm 3,5037$. Skor rata-rata kepatuhan kelompok perlakuan dengan kelompok kontrol yaitu 92, 29 $\pm 4, \quad 5 \%$ dan $84,71 \pm 11, \quad 80 \%{ }^{15}$. Adapun faktor perancu juga dianalisis dalam penelitian ini, antara lain pendidikan terakhir responden. Berdasarkan hasil analisis korelasi antara pendidikan terakhir dengan kepatuhan dalam pengobatan menggunakan uji sommers'd diperoleh hasil sebagai berikut:
Tabel 7. Hasil Uji Korelasi Faktor Perancu

\begin{tabular}{llll}
\hline Value & Signifikansi & $\begin{array}{l}\text { Keeratan } \\
\text { Hubungan }\end{array}$ & Keterangan \\
\hline$-0,166$ & 0,101 & $\begin{array}{l}\text { Sangat } \\
\text { rendah }\end{array}$ & $\begin{array}{l}\text { Tidak } \\
\text { signifikan }\end{array}$ \\
\hline
\end{tabular}

Hasil ini berbeda dengan penelitian terdahulu yang menyatakan bahwa tingkat pendidikan berpengaruh positif terhadap pengetahuan pasien akan pengobatan ( $\mathrm{P}$ $<0, \quad 05): 35,8-56,9 \%$ untuk indikator pemahaman terhadap nama obat, 76, 2-90, 5\% untuk indikator pemahaman terhadap indikasi dan dosis, serta $13,6 \% ; 38$, $1 \% ; 70,0 \%$ untuk indikator pemahaman terhadap efek samping obat bagi kelompok tidak berpendidikan, berpendidikan dasar, dan berpendidikan tinggi ${ }^{16}$.

Setelah melakukan penelitian ini, penulis dapat memberikan beberapa saran, antara lain: (1) Puskesmas diharapkan lebih memperhatikan pemberian informasi obat kepada pasien dalam terapi hipertensi sehingga dapat meningkatkan pengetahuan dan kepatuhan dalam pengobatan, (2) dapat dilakukan penelitian lanjutan mengenai faktor lain yang dapat mempengaruhi kepatuhan dalam pengobatan, dan (3) wilayah jangkauan penelitian diperluas ke Puskesmas lainnya untuk mengevaluasi keberhasilan Prolanis yang dicanangkan oleh Pemerintah melalui BPJS Kesehatan.

\section{DaftarPustaka}

1. Armstrong C. JNC 8 guidelines for the management of hypertension in adults. Am Fam Physician [Internet]. 2014;90(7):503-4. Available from: http://www. aafp. org/afp/2014/1001/p503. html

2. Haldar RN. Global Brief on Hypertension: Silent Killer, Global Public Health Crisis. Indian J Phys Med Rehabil. 2013;24(1):2-2.

3. Kemenkes RI. Laporan Nasional Hasil Riset Kesehatan Dasar (Riskesdas) Indonesia tahun 2018 [Internet]. Riset Kesehatan Dasar 2018. 2018. p. 166. Available from: http://labdata. litbang. kemkes. go. id/images/download/laporan/RKD/2018/Laporan_Nasio nal_RKD2018_FINAL. pdf

4. Dinkes Provinsi Jawa Timur. Profil Kesehatan Jawa Timur 2018. Dinas Kesehat Provinsi Jawa Timur. 2019;100.

5. Menteri Kesehatan RI. Permenkes no 74 tahun 2016 tentang standar pelayanan kefarmasian di puskesmas. kementrian Kesehat RI. 2016;

6. BPJS. Panduan praktis Prolanis (Program pengelolaan penyakit kronis). BPJS Kesehat. 2014;

7. Sari NMV. Hubungan Pengetahuan Tentang Hipertensi Dengan Tingkat Kepatuhan Penggunaan Obat 
Antihipertensi Pada Program Pengelolaan Penyakit Kronis (Prolanis) (Studi Dilakukan Di Puskesmas Beji Dan Puskesmas Batu). Universitas Brawijaya; 2017.

8. Saseen JJ, Maclaughlin EJ. Hypertension. In: Dipiro JT, Talbert RL, Yee GC, Matzke GR, Wells BG, Posey LM, editors. Pharmacotherapy: A Pathophysiologic Approach. 8th ed. The McGraw-Hill Companies, Inc. ; 2011. p. 101-35.

9. Klinik DBFK dan. Pharmaceutical Care untuk Penyakit Hipertensi. Buku. Jakarta: Departemen Kesehatan; 2006. 12-13, 21-24, 55-59 p.

10. Hidayat AAA. Pengantar Ilmu Keperawatan Anak. 2nd ed. Jakarta: Salemba Medika; 2005.

11. Gama IK, Sarmadi IW. Keperawatan Keluarga: Teori dan Praktik. Jakarta: EGC; 2014.

12. Benowitz NL. Antihypertensive Agents. In: Katzung BG, Masters SB, Trevor AJ, editors. Basic and Clinical Pharmacology. 12th ed. New York; 2012. p. 169-91.

13. Wahyuningsih R. Penatalaksanaan Diet pada Pasien. 1st ed. Yogyakarta: Graha Ilmu; 2013.

14. Notoatmodjo S. Metodologi Penelitian Kesehatan. Jakarta: Rineka Cipta; 2010.

15. Ponnusankar S, Surulivelrajan M, Anandamoorthy N, Suresh B. Assessment of impact of medication counseling on patients' medication knowledge and compliance in an outpatient clinic in South India. Patient Educ Couns. 2004;54(1):55-60.

16. Alkatheri AM, Albekairy AM. Does the patients' educational level and previous counseling affect their medication knowledge? Ann Thorac Med. 2013;8(2):105-8. 